\begin{tabular}{|l|l|l||}
\hline \multicolumn{2}{|c|}{ PublisherInfo } \\
\hline \hline PublisherName & $:$ & BioMed Central \\
\hline \hline PublisherLocation & $:$ & London \\
\hline \hline PublisherImprintName & $:$ & BioMed Central \\
\hline \hline
\end{tabular}

\title{
Myc targets
}

\begin{tabular}{|l|c|l||}
\hline \multicolumn{2}{|c|}{ ArticleInfo } \\
\hline \hline ArticleID & $:$ & 4681 \\
\hline \hline ArticleDOI & $:$ & $10.1186 /$ gb-spotlight-20030120-01 \\
\hline \hline ArticleCitationID & $:$ & spotlight-20030120-01 \\
\hline \hline ArticleSequenceNumber & $:$ & 33 \\
\hline \hline ArticleCategory & $:$ & Research news \\
\hline ArticleFirstPage & $:$ & 1 \\
\hline \hline ArticleLastPage & $:$ & 2 \\
\hline \hline & & RegistrationDate : 2003-1-20 \\
\hline ArticleHistory & $:$ & OnlineDate \\
\hline \hline ArticleCopyright & $:$ & BioMed Central Ltd2003-1-20 \\
\hline \hline ArticleGrants & $:$ & \\
\hline \hline ArticleContext & $:$ & 130594411 \\
\hline \hline
\end{tabular}




\section{Jonathan B Weitzman}

Email: jonathanweitzman@hotmail.com

There is intense effort to identify transcriptional targets of the c-Myc proto-oncogene that can account for its role in cell growth and division. In the January 16 Nature Gomez-Roman et al. report that c-Myc directly activates transcription by RNA polymerase III (pol III) (Nature 2003, 421:290-294). Analysis of human fibroblasts and cells from c-myc knockout mice, showed that c-Myc is important for the transcription of pol-III-regulated genes, such as the B2 repetitive gene family, 5S rRNA and tRNA genes. Chromatin immunoprecipitation experiments showed that c-Myc is associated with pol III target genes in vivo. Gomez-Roman et al. report a direct interaction between the regulatory domain of c-Myc and TFIIIB, a pol-III-specific general transcription factor. These new Myc targets help explain how cMyc regulates growth by activating pol-II- and pol-III-dependant transcriptional programs.

\section{References}

1. Cell growth: downstream of Myc - to grow or to cycle?

2. Nature, [http://www.nature.com]

This PDF file was created after publication. 